\title{
0083. Hepatoprotective effects of hydrogen sulphide against acute liver failure
}

\author{
K Tokuda ${ }^{1,2^{*}}$, F Ichinose ${ }^{2}$ \\ From ESICM LIVES 2014 \\ Barcelona, Spain. 27 September - 1 October 2014
}

\begin{abstract}
Introduction
Acute liver failure is a fatal syndrome attributed to massive hepatocyte apoptosis that is resistant to conventional medical therapies. Consequently, liver transplantation is required in many cases. An experimental liver failure model induced by galactosamine (Gal) and lipopolysaccharide (LPS) mimics clinical acute liver failure. In this model, LPS stimulates macrophages to release TNF $\alpha$, which induces apoptosis in Gal-sensitized hepatocytes, causing acute liver failure. Hydrogen sulphide $\left(\mathrm{H}_{2} \mathrm{~S}\right)$, which is an endogenously produced gaseous signaling molecule, has anti-apoptotic as well as anti-inflammatory properties. Previously, we reported that $\mathrm{H}_{2} \mathrm{~S}$ attenuates liver dysfunction arising from LPS-induced systemic inflammation [1]. It has also been reported that $\mathrm{H}_{2} \mathrm{~S}$ reduces hepatic ischemia/reperfusion injury by inhibition of apoptosis in the liver [2]. However, it is still unknown whether $\mathrm{H}_{2} \mathrm{~S}$ exerts hepatoprotective effects against acute liver failure, in which both inflammatory responses and apoptosis have critical roles. Here, we examined the impact of $\mathrm{H}_{2} \mathrm{~S}$ on acute liver failure in mice induced by Gal and LPS.
\end{abstract}

\section{Methods}

Mice were challenged with saline or combination of Gal and LPS intraperitoneally, then divided into two groups: one group breathed air alone, and another breathed $\mathrm{H}_{2} \mathrm{~S}$ (80 $\mathrm{ppm})$ for $6 \mathrm{~h}$ followed by breathing air.

\section{Results}

Mice that breathed air after Gal/LPS challenge showed poor survival rate (13\%) and marked increase of alanine aminotransferase (ALT) and aspartate aminotransferase (AST) in plasma. On the other hand, $\mathrm{H}_{2} \mathrm{~S}$ inhalation for $6 \mathrm{~h}$ after challenge markedly improved survival $(60 \%, p<$

\footnotetext{
${ }^{1}$ Kyushu University Hospital, Intensive Care Unit, Fukuoka, Japan
}

Full list of author information is available at the end of the article
0.05) and suppressed Gal/LPS-induced elevation of ALT and AST levels in plasma. Inhaled $\mathrm{H}_{2} \mathrm{~S}$ suppressed TNF $\alpha$ in plasma at $1 \mathrm{~h}$ after Gal/LPS challenge. Mice that breathed air after Gal/LPS challenge exhibited activation of caspase 3, 8, and 9 in the liver, whereas $\mathrm{H}_{2} \mathrm{~S}$ breathing inhibited activation of caspase 3,8 , and 9 , suggesting inhaled $\mathrm{H}_{2} \mathrm{~S}$ after Gal/LPS challenge suppressed both extrinsic and intrinsic pathways of caspase-dependent apoptosis in the liver. Gal/LPS challenge increased phosphorylated STAT3 transcription factor. $\mathrm{H}_{2} \mathrm{~S}$ inhalation after Gal/LPS challenge further augmented phosphorylation of STAT3 compared to air alone. The protective effects of $\mathrm{H}_{2} \mathrm{~S}$ inhalation after Gal/LPS challenge were associated with upregulation of gene expression of antiinflammatory IL-10, which stimulates STAT3 phosphorylation, in the liver. These results suggest that inhaled $\mathrm{H}_{2} \mathrm{~S}$ contributes to survival of mice in acute liver failure at least in part through activation of IL-10/STAT3 pathway.

\section{Conclusions}

These results suggest that $\mathrm{H}_{2} \mathrm{~S}$ shows hepatoprotective effects against acute liver failure at least in part by inhibition of caspase activation and by augmentation of IL-10/STAT3 signaling pathway in the liver.

\footnotetext{
Authors' details

${ }^{1}$ Kyushu University Hospital, Intensive Care Unit, Fukuoka, Japan.

${ }^{2}$ Massachusetts General Hospital, Department of Anesthesia, Critical Care and Pain Medicine, Charlestown, MA, USA.

Published: 26 September 2014

\section{References}

1. Tokuda K: Inhaled hydrogen sulfide prevents endotoxin-induced systemic inflammation and improves survival by altering sulfide metabolism in mice. Antioxid Redox Signal 2012, 17:11-21.

2. Jha S: Hydrogen sulfide attenuates hepatic ischemia-reperfusion injury: role of antioxidant and antiapoptotic signaling. Am J Physiol Heart Circ Physiol 2008, 295:H801-806.
}

(c) 2014 Tokuda and Ichinose; licensee Springer. This is an Open Access article distributed under the terms of the Creative Commons Attribution License (http://creativecommons.org/licenses/by/2.0), which permits unrestricted use, distribution, and reproduction in any medium, provided the original work is properly cited. 
doi:10.1186/2197-425X-2-S1-P3

Cite this article as: Tokuda and Ichinose: 0083. Hepatoprotective effects

of hydrogen sulphide against acute liver failure. Intensive Care Medicine

Experimental 2014 2(Suppl 1):P3.

\section{Submit your manuscript to a SpringerOpen ${ }^{\mathcal{D}}$ journal and benefit from:}

- Convenient online submission

- Rigorous peer review

- Immediate publication on acceptance

- Open access: articles freely available online

- High visibility within the field

- Retaining the copyright to your article

Submit your next manuscript at $\gg$ springeropen.com 